\title{
Pengembangan Media Pembelajaran Video Animasi Dua Dimensi Situs Pekauman di Bondowoso Dengan Model Addie Mata Pelajaran Sejarah Kelas X IPS \author{
(The Development of Two Dimensional Animation Video of Pekauman
} Website as Instructional Media With Addie Model in Bondowoso in The History Subject of Class IPS X)
}

\author{
Relis Agustien, Nurul Umamah, Sumarno \\ Pendidikan Sejarah, Fakultas Keguruan dan Ilmu Pendidikan, Universitas Jember (UNEJ) \\ Jln. Kalimantan 37, Jember 68121 \\ E-mail: umamahnurul@ymail.com
}

\begin{abstract}
Abstrak
Pengembangan media pembelajaran yang berkualitas dan inovatif serta aplikatif menjadi tuntutan pada era modern ini. Oleh karena itu pendidik diharapkan mempunyai kemampuan untuk memanfaatkan teknologi modern sebagai media untuk membantu proses belajar mengajar dan meningkatkan kualitas pembelajaran. Penelitian ini bertujuan menghasilkan produk media pembelajaran video animasi dua dimensi. Subjek penelitian ini adalah kelas X IPS 2 SMAN 1 Tapen dengan jumlah 26 peserta didik. Penelitian dilakukan pada bulan Januari-Februari 2018. Hasil penelitian menunjukkan produk media pembelajaran tervalidasi dan dalam kategori menarik. Secara klasikal hasil validasi ahli isi bidang studi sebesar $80 \%$, validasi ahli media dan desain pembelajaran sebesar $78 \%$. Tingkat daya tarik pada penelitian ini sebesar $84 \%$ pada uji coba kelompok kecil, dan $87 \%$ pada uji kelompok besar. Kesimpulan penelitian ini bahwa media pembelajaran video animasi dua dimensi tervalidasi ahli dan menarik
\end{abstract}

Kata kunci: Media Pembelajaran, Video Animasi Dua Dimensi, Validasi Ahli, Daya Tarik.

\section{Abstract}

The development of quality, innovative and applicative instructional media to be demanded in this modern era. Therefore educators are expected to have the ability in utilizing the modern technology as a medium in helping the teaching and learning process and improving the quality of learning. This study is aimed to produce two dimensional animated video as instructional media. The subjects of this study were 26 Students of class X IPS 2 of SMAN 1 Tapen. The study was conducted in January-February 2018. The results showed that the product of instructional media was validated and in the interesting category. Classically, the results of expert validation of content in the field of study was $80 \%$, the validation of media expert and learning design was $78 \%$. The attractiveness rate in this study was $84 \%$ in small group trial, and $87 \%$ in large group trial. The conclusion of this research was that two dimensional animation video as instructional media was expertly validated and interesting.

Keywords: Instructional Media, Two Dimensional Animation Video, Expert Validation, Attraction.

\section{Pendahuluan}

Kurikulum 2013 menempatkan sejarah sebagai mata pelajaran kelompok A (wajib) yang diberikan pada jenjang pendidikan menengah (SMA/MA dan SMK/MAK). Mata pelajaran Sejarah Indonesia memiliki arti strategis untuk membentuk watak dan peradaban bangsa yang bermartabat serta membentuk manusia Indonesia yang memiliki rasa kebangsaan dan inta tanah air. Dengan demikian, tujuan dari pembelajaran sejarah adalah membelajarkan peserta didik agar dapat mengambil nilai-nilai dari kehidupan masa lampau untuk direfleksikan pada kehidupan saat ini [1]. Hal ini menempatkan mata pelajaran sejarah sebagai salah satu sendi penting dalam pendidikan.
Kualitas pembelajaran sejarah dipengaruhi oleh komponen-komponen pendidikan yaitu antara lain pendidik, peserta didik, sarana dan prasarana serta lingkungan. Pendidik merupakan komponen terpenting dalam pembelajaran sejarah karena pendidik berinteraksi langsung dengan peserta didik. Pendidik yang berkualitas adalah pendidik yang memiliki kompetensi pedagogik. Kompetensi pedagogik merupakan kemampuan dalam pengelolaan peserta didik, yaitu mampu melaksanakan pembelajaran yang mendidik dengan suasana dialogis dan interaktif, sehingga pembelajaran menjadi aktif, inovatif, kreatif, efektif dan menyenangkan [2]. Pendidik juga dituntut memiliki kreativitas dalam pengembangan desain pembelajaran dan mengimplementasikannya [3]. Salah satunya adalah dengan memanfaatkan media pembelajaran. 
Media adalah sumber belajar sehingga secara luas media pembelajaran dapat diartikan dengan manusia, benda ataupun peristiwa yang memungkinkan peserta didik memperoleh pengetahuan serta keterampilan. Media merupakan alat bantu yang dapat berupa apa saja untuk dijadikan sebagai penyalur pesan guna mencapai tujuan pembelajaran [4]. Menurut Hamalik (dalam Ainina) hadirnya media pembelajaran merupakan salah satu komponen dalam proses pembelajaran yang sangat diperlukan, mengingat bahwa kedudukan media bukan hanya sekedar alat bantu mengajar, tetapi lebih merupakan bagian yang tak terpisahkan dalam proses pembelajaran [5]. Media pembelajaran selain dapat menggantikan sebagian tugas pendidik sebagai penyaji materi, media juga memiliki potensi-potensi yang unik yang dapat membantu peserta didik dalam belajar. Oleh sebab itu, perlu dikembangkan media pembelajaran yang kreatif yang dapat meningkatkan daya tarik peserta didik untuk belajar sejarah. Beberapa alternatif media pembelajaran yang dapat dimanfaatkan dalam pembelajaran sejarah salah satunya adalah media video.

Video merupakan suatu media yang sangat efektif untuk membantu proses pembelajaran. Video kaya akan informasi dan tuntas karena sampai kehadapan peserta didik secara langsung [6]. Video menambah dimensi baru terhadap pembelajaran sejarah. Sebab video dapat menyajikan gambar bergerak dan bersuara pada peserta didik. Kemampuan video dalam memvisualisasikan materi sangat efektif untuk membantu pendidik menyampaikan materi yang bersifat dinamis.

Pengemasan media video ini dikombinasikan dengan animasi. Animasi adalah suatu kegiatan menghidupkan, menggerakkan benda diam. Suatu benda diam diberikan dorongan kekuatan, semangat dan emosi untuk menjadi hidup dan bergerak atau hanya berkesan hidup [7]. Jadi animasi merupakan objek diam yang diproyeksikan menjadi gambar bergerak yang seolah-olah hidup sesuai dengan karakter yang dibuat dari beberapa kumpulan gambar yang berubah beraturan dan bergantian sesuai dengan rancangan, sehingga video yang ditampilkan lebih variatif dengan gambar-gambar menarik dan berwarna yang mampu meningkatkan daya tarik belajar peserta didik.

Pada implementasinya, penggunaan media pembelajaran belum digunakan secara maksimal sebagai sarana pembelajaran sejarah. Berdasarkan hasil observasi awal diperoleh informasi bahwa sekolah hanya menyediakan buku paket pelajaran sebagai sumber belajar pokok dan lembar kerja siswa (LKS) sebagai penunjang. Buku-buku tersebut berupa teks yang enderung bersifat informatif sehingga kurang menarik perhatian peserta didik dalam belajar sejarah. Hasil wawanara dengan pendidik diperoleh informasi bahwa pihak sekolah sudah menyediakan sarana media belajar seperti LCD dan proyektor. Namun penggunaannya masih terbatas pada media power point dan video sesekali yang diambil dari internet.

Berkenaan dengan hasil observasi dan wawancara yang diperoleh tersebut, maka perlu dikembangkan media pembelajaran yang dapat meningkatkan daya tarik peserta didik dalam pembelajaran sejarah. Ketertarikan peserta didik dalam menggunakan media pembelajaran juga pernah diteliti oleh Gustiningrum (2014) pada penelitiannya yang berjudul
"Pengembangan Media Animasi dengan Macromedia Flash pada Pembelajaran Sejarah Kelas X Menggunakan Model ASSURE" [8]. Hasil uji coba kelompok kecil dengan responden peserta didik kelas X MIPA 4 menunjukkan $80,11 \%$ media pembelajaran yang telah direvisi berada pada kualifikasi baik dan menarik, serta pada uji coba lapangan dengan responden peserta didik menunjukkan $88 \%$ pada kualifikasi sangat menarik.

Penelitian yang dilakukan oleh Putri (2016) dengan judul "Pengembangan Media Pembelajaran Berbasis Video Animasi Pada Mata Pelajaran Sejarah Kelas X SMA dengan Model Borg And Gall". Hasil daya tarik peserta didik pada uji coba kelompok kecil menunjukkan 84,6\% dengan kualifikasi menarik, sedangkan daya tarik peserta didik pada uji coba kelompok besar mencapai 89,6\% dengan kualifikasi sangat menarik.

Berdasarkan uraian hasil daya tarik dari penelitian terdahulu seputar media pembelajaran, produk media video animasi berkategori baik dan layak digunakan. Hal ini mendorong peneliti untuk melakukan pengembangan dengan judul "Pengembangan Media Pembelajaran Video Animasi Dua Dimensi Situs Pekauman di Bondowoso dengan Model ADDIE Mata Pelajaran Sejarah Kelas X IPS”.

\section{Metode Penelitian}

Jenis penelitian ini adalah penelitian pengembangan yang dilakukan di SMAN 1 Tapen. Subjek penelitian ini adalah peserta didik kelas X IPS 2 dengan jumlah 26 orang terdiri dari 17 laki-laki dan 9 perempuan.

Rancangan penelitian ini menggunakan model ADDIE. Model ADDIE memiliki 5 tahapan, yaitu: (1) Analyze (menganalisis), (2) Design (merancang), (3) Development (mengembangkan), (4) Implementation (mengimplementasi -kan), (5) Evaluation (mengevaluasi).

Teknik pengumpulan data dilakukan dengan cara observasi, dokumentasi dan angket. Analisis data validasi ahli diperoleh dari penilaian ahli isi bidang studi, ahli media dan desain pembelajaran berdasarkan angket yang diberikan.

Data tersebut kemudian dianalisis dengan rumus:

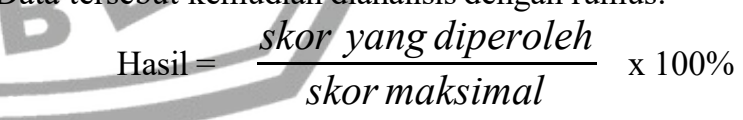

Tabel 1. Kategori Kelayakan Produk Media Video Animasi Dua Dimensi

\begin{tabular}{ccc}
\hline Tingkat Pencapaian & Kualifikasi & Keterangan \\
\hline $85 \%-100 \%$ & Sangat baik & Tidak perlu direvisi \\
$75 \%-84 \%$ & Baik & Tidak perlu direvisi \\
$65 \%-74 \%$ & Cukup & Direvisi \\
$55 \%-64 \%$ & Kurang & Direvisi \\
$0-54 \%$ & Kurang sekali & Direvisi \\
\hline
\end{tabular}

Untuk menguji tingkat kemenarikan media pembelajaran video animasi dua dimensi pada uji coba kelompok kecil dan uji coba kelompok besar digunakan rumus:

$$
\mathrm{F}=\frac{\text { jumlah persentaseindikator }}{\text { jumlahindikator }} \times 100 \%
$$

$\mathrm{F}=$ Persentase daya tarik

Tabel 2. Persentase Daya Tarik Media Video Animasi Dua Dimensi 


\begin{tabular}{cc}
\hline Hasil Pencapaian & Kategori \\
\hline $85 \%-100 \%$ & Sangat Tinggi \\
$75 \%-84 \%$ & Tinggi \\
$65 \%-74 \%$ & Sedang \\
$55 \%-64 \%$ & Rendah \\
$0-54 \%$ & Sangat Rendah \\
\hline
\end{tabular}

\section{Hasil dan Pembahasan}

Hasil dari penelitian pengembangan ini adalah produk media pembelajaran video animasi dua dimensi yang siap divalidasi ahli dan di uji daya tariknya. Berikut dipaparkan tentang sajian dan analisis data hasil tanggapan/penilaian ahli isi bidang studi, ahli media dan desain pembelajaran, uji coba pengguna, uji coba kelompok kecil dan uji coba kelompok besar.

\section{Validasi Ahli}

Berikut akan dipaparkan analisis data serta tanggapan ahli isi bidang studi, ahli media dan desain pembelajaran menggunakan media video animasi dua dimensi.

a. Validasi Ahli Isi Bidang Studi

Validasi ahli isi bidang studi adalah Bapak Drs. Sumarno, M.Pd. Hasil analisis data validasi ahli isi bidang studi diperoleh nilai presentase $80 \%$. Jika disesuaikan dengan tabel kelayakan, maka produk yang dikembangkan masuk ke dalam kualifikasi baik. Artinya, media pembelajaran ini sangat baik digunakan untuk peserta didik. Kemudian dapat ditafsirkan pula bahwa produk pengembangan ini tidak perlu direvisi.

b. Validasi Ahli Media dan Desain Pembelajaran

Validasi ahli media dan desain pembelajaran dilakukan oleh Ibu Ruli Putri Puji Nirmala, S.Pd. M.ed. Hasil analisis data validasi ahli media dan desain pembelajaran diperoleh nilai presentase $78 \%$ yang dinyatakan masuk dalam kategori "Baik". Adapun komentar dan saran yang diberikan adalah layout tulisan situs mohon diganti warna baground putih dan tulisan hijau tua bukan hijau muda, sertakan cuplikan gambar asli situs seperti cuplikan pada peninggalan sarkofagus.

\section{Uji Coba Produk}

Uji coba produk media pembelajaran video animasi dua dimensi dilakukan kepada subjek penelitian yang meliputi pendidik sebagai pengguna dan peserta didik dalam uji coba kelompok kecil serta uji coba kelompok besar.

a. Uji Pengguna

Uji pengguna dilakukan pada pendidik mata pelajaran sejarah yaitu Bapak As'ari, S.Pd. Hasil analisis data uji pengguna diperoleh nilai presentase sebesar 88\% yang dinyatakan masuk dalam kategori "Sangat Baik". Adapun komentar dan saran yang diberikan diantaranya: (1) materi yang disajikan dikembangkan lebih luas lagi, (2) dubbing suara kurang jelas.

\section{b. Uji Coba Kelompok Kecil}

Uji coba kelompok kecil melibatkan 6 peserta didik kelas X IPS SMAN 1 Tapen. Analisis data berdasarkan uji coba kelompok kecil dengan 6 responden diperoleh presentase tiap-tiap peserta didik yaitu $84 \%, 82 \%, 82 \%, 86 \%, 86 \%$, $84 \%=504$, kemudian dibagi banyaknya responden sehingga dapat diperoleh rata-ratanya yaitu $84 \%$. Sehingga diperoleh kategori produk "Baik".

\section{c. Uji Coba Kelompok Besar}

Uji coba kelompok besar dilakukan kepada 26 peserta didik kelas X IPS SMAN 1 Tapen. Analisis data berdasarkan uji daya tarik produk yang dilakukan kepada 26 peserta didik diperoleh nilai presentase sebesar 87\%, sehingga diperoleh kategori produk "Sangat Baik".

\section{Daya Tarik Peserta Didik terhadap Media Video Animasi Dua Dimensi}

Daya tarik adalah kemampuan untuk menarik atau memikat perhatian. Setiap bidang studi memiliki daya tarik tersendiri bagi peserta didik. Daya tarik pembelajaran dapat dibentuk melalui perancangan kualitas pembelajaran. Peranan strategi pengorganisasian pendidik pada mata pelajaran sejarah sangat menentukan daya tarik peserta didik. Semakin baik kualitas pembelajaran, semakin besar daya tarik yang ditimbulkan. Variabel penting yang dijadikan dasar sebagai indikator daya tarik adalah penghargaan dan keinginan lebih, sehingga titik awal kemenarikan pembelajaran dapat diciptakan melalui pengorganisasian, penyampaian, dan pengelolaan pembelajaran [9]. Hal ini menegaskan bahwa daya tarik pembelajaran dapat diciptakan melalui pengelolaan pembelajaran yang terorganisir.

Pengelolaan pembelajaran salah satunya dapat diciptakan dengan memanfaatkan media pembelajaran dalam proses belajar mengajar. Media pembelajaran mampu mengubah materi abstrak menjadi lebih konkret. Pemanfaatan media pembelajaran sebagai penunjang belajar diharapkan mampu meningkatkan daya tarik peserta didik dalam belajar sejarah sehingga tingkat pemahaman peserta didik semakin berkembang. Peningkatan pemahaman peserta didik terhadap suatu materi pembelajaran dapat meningkatkan prestasi belajar peserta didik. Pencapaian prestasi belajar yang baik dengan pencapaian tujuan pembelajaran yang hendak dicapai. Media dalam pencapaian tujuan pembelajaran harus memenuhi indikator daya tarik untuk menarik konsentrasi peserta didik. Adapun indikator daya tarik terhadap media pembelajaran menurut Slameto (2003:58) antara lain: (1) peserta didik senang belajar dengan menggunakan media video animasi dua dimensi; (2) peserta didik mudah menggunakan media yideo animasi dua dimensi; (3) peserta didik antusias menggunakan media video animasi dua dimensi; (4) peserta didik memperhatikan media video animasi dua dimensi; (5) peserta didik memahami materi dari media video animasi dua dimensi [10].

Ketertarikan peserta didik menggunakan media untuk meningkatkan daya tarik dalam pembelajaran juga pernah diteliti oleh Putri (2016) pada penelitiannya yang berjudul "Pengembangan Media Pembelajaran Berbasis Video Animasi pada Mata Pelajaran Sejarah Kelas X SMA dengan Model Borg And Gall” [11]. Hasil uji coba kelompok kecil dengan responden 9 peserta didik kelas X SMAN 1 Penarukan menunjukkan $84,6 \%$ media pembelajaran yang telah direvisi berada pada kualifikasi baik dan menarik, serta uji coba kelompok besar dengan responden 30 peserta didik kelas X IPS 4 SMAN 2 Situbondo menunjukkan 89,6\% media pembelajaran berada pada kualifikasi tinggi dan sangat menarik. Hasil penilaian peserta didik menunjukkan bahwa media pembelajaran berada pada kualifikasi baik dan mampu meningkatkan daya tarik peserta didik dalam pembelajaran sejarah. 
Berdasarkan uraian kriteria daya tarik dan penelitian terdahulu seputar media pembelajaran tersebut, pengembang menjabarkan komponen daya tarik tersebut ke dalam angket uji coba. Komponen-komponen tersebut disesuaikan dengan karakteristik media video animasi dua dimensi sehingga tertera 10 indikator daya tarik media dalam angket peserta didik. Pengembangan media pembelajaran video animasi dua dimensi ini akan diuji kevalidan dan daya tarik pengguna medianya. Pengukuran daya tarik media yang digunakan ditinjau berdasarkan angket daya tarik peserta didik sesaat setelah menggunakan produk masing-masing untuk uji coba kelompok kecil dan uji coba kelompok besar.

Pembelajaran sejarah dengan menggunakan media video animasi dua dimensi terbukti dapat meningkatkan daya tarik peserta didik. Hal ini dapat ditinjau dari angket daya tarik yang diisi oleh peserta didik saat uji coba kelompok kecil dan uji coba kelompok besar. Hasil angket daya tarik media video animasi dua dimensi pada uji coba kelompok kecil mencapai persentase $84 \%$ dengan kualifikasi tinggi. Persentase tersebut atas dasar indikator rasa senang, kemudahan pengguna, antusias penggunanya, perhatian dan pemahaman media video animasi dua dimensi.

Uji coba kelompok besar juga menunjukkan persentase tinggi dengan capaian $87 \%$ untuk uji daya tarik media video animasi dua dimensi oleh peserta didik. Hasil tersebut jika dicocokkan dengan tabel persentase daya tarik, maka masuk dalam kualifikasi sangat tinggi. Hal ini membuktikan bahwa belajar sejarah dengan menggunakan media pembelajaran video animasi dua dimensi sangat menyenangkan dan memikat daya tarik peserta didik untuk antusias dalam penggunaan, meningkatkan perhatian dan menggali pemahaman seputar materi yang disajikan

Berdasarkan uji coba kelompok kecil dan uji coba kelompok besar, produk media video animasi dua dimensi berkategori baik dan layak untuk digunakan. Produk media video animasi dua dimensi dapat meningkatkan daya tarik peserta didik terhadap pembelajaran sejarah sehingga dapat meningkatkan kualitas pembelajaran sejarah.

\section{Kesimpulan dan Saran}

\section{Kesimpulan}

Berdasarkan hasil analisis data, pembahasan, dan hasil pengembangan media pembelajaran video animasi dua dimensi situs pekauman di Bondowoso dengan model ADDIE mata pelajaran sejarah kelas X IPS, dapat diambil kesimpulan sebagai berikut:

a. media pembelajaran video animasi dua dimensi situs pekauman di Bondowoso dengan model ADDIE telah tervalidasi ahli, yaitu: (1) validasi ahli isi bidang studi mendapatkan nilai presentase sebesar $80 \%$ dan termasuk dalam kategori "Baik", (2) validasi ahli media dan desain pembelajaran mendapatkan nilai presentase sebesar $78 \%$ dan termasuk dalam kategori "Baik".

b. media pembelajaran video animasi dua dimensi juga telah melalui tahap uji daya tarik pengguna yaitu pendidik dan peserta didik melalui uji coba kelompok kecil dan uji coba kelompok besar. Daya tarik pendidik terhadap media video animasi dua dimensi diperoleh nilai presentase sebesar $88 \%$ dan termasuk dalam kategori "Sangat Menarik", daya tarik peserta didik terhadap media video animasi dua dimensi pada uji coba kelompok kecil mendapatkan nilai presentase $84 \%$ yang termasuk kategori "Menarik", dan daya tarik peserta didik terhadap media video animasi dua dimensi pada uji coba kelompok besar mendapatkan nilai presentase $87 \%$ yang termasuk kategori "Sangat Menarik".

\section{Saran}

Berdasarkan uji coba produk yang telah dilaksanakan, saran yang dapat diberikan atas pemanfaatan media pembelajaran video animasi dua dimensi situs pekauman di Bondowoso dengan model ADDIE adalah sebagai berikut:

\section{a. Kepala Sekolah}

Sekolah sebagai penyelenggara pilar pendidikan, hendaknya mampu mengimplementasikan peraturan resmi yang berkaitan dengan kegiatan pembelajaran terutama pengimplementasian kurikulum 2013, sehingga dapat tercapainya tujuan pendidikan secara maksimal.

\section{b. Pendidik}

Pendidik memiliki peran yang sangat penting dalam membantu peserta didik untuk mampu mencapai tujuan pembelajaran, oleh karena itu hendaknya pendidik juga memiliki pemahaman yang baik sebagai fasilitator.

\section{c. Peserta Didik}

Peserta didik diharapkan memiliki kesadaran dalam pemenuhan kebutuhan akan kompetensi yang harus dicapai. Terlebih dalam pemanfaatan teknologi dan informasi dewasa ini.

\section{Ucapan Terima Kasih}

Peneliti mengucapkan terima kasih kepada Kepala SMAN 1 Tapen yang telah memberikan izin untuk melakukan penelitian. Peneliti juga berterima kasih kepada Bapak As'ari, S.Pd selaku pendidik mata pelajaran sejarah kelas X IPS 2 yang telah membantu selama proses penelitian, serta peserta didik kelas X IPS 2 yang telah menjadi subjek penelitian

\section{Daftar Pustaka}

[1] Kochhar, S. K. 2008. Pembelajaran Sejarah (Teaching of History). Jakarta: PT Grasindo.

[2] Sagala, S. 2009. Konsep dan Makna Pembelajaran. Bandung: Alfabeta.

[3] Umamah, N. 2017. Pembelajaran Sejarah Kesiapannya Menghadapi Tantangan Jaman. Paper hal.1-14: Dosen Prodi Pendidikan Sejarah FKIP-UNEJ. Diakses pada tanggal 20 maret 2018.

[4] Djamarah, S. B. 2010. Belajar Mengajar. Jakarta: Rineka Cipta.

[5] Ainina, I. A. 2014. Pemanfaatan Media Audio Visual sebagai Sumber Pembelajaran Sejarah. Indonesia Journal Of History Education, Vol.3 (1) Tahun 2014.

[6] Daryanto, dan Rahardjo, M. 2012. Model Pembelajaran Inovatif. Yogyakarta: Gava Media.

[7] Syahfitri, Y. "Teknik Animasi dalam Dunia Komputer". Jurnal SAINTIKOM. September 2011. Halaman 1-3. Vol. 10/No.3.

[8] Gustiningrum, E. 2014. Pengembangan Media Animasi dengan Macromedia Flash Pada Pembelajaran Sejarah Kelas X Menggunakan Model ASSURE. Skripsi. Jember: Universitas Jember.

[9] Degeng, I.N.S. 1989. Ilmu Pengajaran Taksonomi Variabel. Jakarta: Departemen Pendidikan Dan Kebudayaan.

[10] Slameto. 2003. Belajar dan Faktor-faktor yang Mempengaruhi. Jakarta: Rineka Cipta. 
[11] Putri, R.A. 2016. Pengembangan Media Pembelajaran Berbasis Video Animasi Pada Mata Pelajaran Sejarah Kelas X SMA dengan Model Borg And Gall. Skripsi. Jember: Universitas Jember.

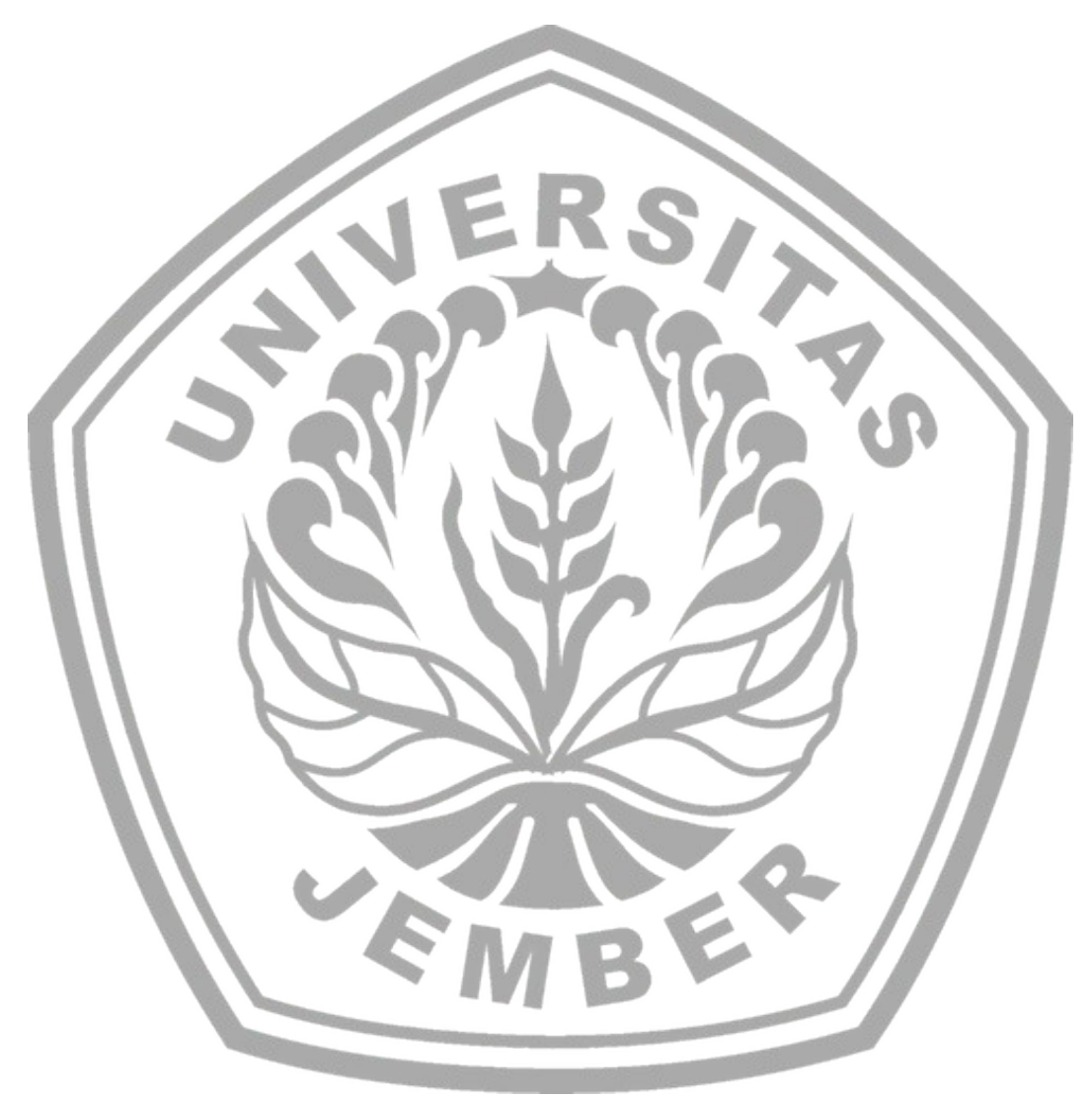

